\title{
The Implementation of TRIPs-WTO in the Protection of IPR over Fashion Trademark of Creative Industry as an Effort to Improve Global Competitiveness
}

\author{
Nina Nurani
}

\begin{abstract}
This study examines how the protection of IPR, regarding Trademark serving as the implementation of TRIPsWTO, provides protection over fashion of the creative industry and how the protection of trademark rights over this product improves the global competitiveness. Normative-jurisdical method is applied to this study.

The Law No 15 year 2001 regarding Trademark serving as the implementation of TRIPs-WTO, has not fully provided protection over the fashion products of the creative industry, making it being ineffectively conducted by the product owners.

Trademark protection for these products has not met the hope of the owners of creative industry in protecting their trademarks to be able to compete globally. The obstacles that hamper are juridical,cultural, philosophical,sociologicaland international aspects. The former consists of improper management, complex bureaucracy for registration.

The government needs to do an obvious way by extending the Trademark Law.
\end{abstract}

Index Terms-TRIPs-WTO, IPR protection over trademark, fashion products, creative industry, global competitiveness.

\section{BACKGROUND}

Globalization has changed the society in their characters, life style, and attitudes to a way that is more critical and considerate. This leads to global market expansion and demands a tougher competitiveness [1]. This state requires the company to figure out a way to suppress the cost efficiently. Industrial concentration has now shifted from the Western to Asia's Developing Countries due to the fact that they cannot complete the low cost production implemented by the Republic of China and the industrial efficiency policy of Japan. The developed countries realize that they cannot rely heavily on their industrial supremacy, but should take into account their creative Human Resources [1]. This will emerge creativity, meaning that the economic shall be driven by the creative industries.

Indonesia has potentially promising creative industries. It is estimated that $50 \%$ of consumer spending in G7 countries originate from the products of creative industry [1] whereas the consumer spending itself comprises $2 / 3$ of the Gross Domestic Product. At this point, it can be estimated that the

Manuscript received January 27, 2014; revised March 26, 2014. The paper is an outcome of a competence research by the Higher Educational Directorate of the Indonesia National Education Department under grant number: 043/SP2H/PL/DIT.LITABMAS/V/2013. The author wants to thank all contributors to this project, especially: Nugroho, Agoestiana and Lia Amaliawiati who did most of the share ideas.

The author is with Fakulty of Business Management, Widyatama University, West Java, Indonesia (e-mail: nina.nurani@ widyatama.ac.id). potential market of this industry is $50 \% \times 2 / 3$ of the GDP. This is crucial considering the fact that US, England, France, Canada, Italy, and Japan are the export destinations of the developing countries, including Indonesia [2].

Creative industry, which has 14 sub sectors, had proven to be able to contribute significantly on Indonesia GDP on the average of $6.3 \%$ in 2002-2006. Additionally, it contributed 5.8\% of average employment in 2002-2006, and $10.6 \%$ [3] to the total export average in 2002-2006, and eksport contributed $13 \%$ [4].

Of the 14 sub sectors, Fashion is the one that dominantly contributes to the economic, in both improved value of workers, number of companies, and the exports. In 2006, the added value created by the Fashion sub sector was 43, 71 from the total contribution of the creative industry sector. In addition, the average employment was $53.52 \%$, the number of companies was 56.37\%, and the export was $65.73 \%$ [5]. In the other hand, in 1999 the potential market of this sub sector in global market was 12 million US\$, 5 million US\$ in US, and 1 million US\$ in UK [6].

The domination of this sub sector is in line with the Indonesia's cultural diversity from Sabang to Merauke. In Indonesia, fashion industry is one of the most interesting. The existence of many factory outlets and distro (shop of clothes) indicates that fashion industry is a solid sub sector.

In consequence, this sub sector requires an explicit regulation regarding the certainty of the law protection for the creator. This guarantee creates pleasant atmosphere to develop the sub sector, considering the piracy [7] over famous fashion trademark. One of the cases was the piracy over Versace by a few boutiques in US. Versace won the compensation of 20 million US\$ (Rp 184 billion) [8]. Nevertheless, Intellectual Property Right (IPR) is required to prevent piracy or falsification.

Globalization is centrifugal movement of market based on the competition. Free trade may enlarge the gap between the developed countries and the "under-developed" countries, [9] at the same time may demand Indonesia's negotiation strengthening and strategic approach among international countries. Therefore, global dimension aspect is required as a strategic plan that challenges Indonesia Law to go face to face with the world, [9] to be able to communicate through laws with other nations, [10] and to be able to fulfil the needs of the society in the global era. This demands the establishment of the treaty of Uruguay's GATT, which is TRIPs (Trade Related Aspects of Intellectual Property Rights Including Trade in Counterfeit Goods), or known as Commercial Treaty having to do with Intellectual Property 
Right (IPR) focusing on the trading of fake products.

IPR, as the manifestation of system of international economic policy and is important for Indonesia businesses, urges Indonesia to adjust its law system of IPR because the TRIPs-WTO requires the law to meet the full compliance principles. This means that the member countries must provide its IPR national law in accordance with the TRIPsWTO treaty [11].

The IPR issue is a supporting idea for the trans-national companies $(\mathrm{MNc})$, in which the impacts will go to the small and poor countries. The WTO may be made use for the western particular interests [11]. The existing problems in Indonesia are related to technological literacy and human resources qualification resulting in weak competitiveness. IPR relates to society's innovation and creativity; which its current state is relatively poor due to the communal culture of particular intellectual property.

As the implementation of TRIPs-WTO treaty and to build the system of IPR national law, in terms of improving society's awareness of IPR, the government of Indonesia has issued the IPR policy. The policy is the Laws No 15 year 2001 regarding Trademark which is expected to prevent the creative industry products - fashion for example-from piracy or fabricating in their global competition.

In relation to global market, the trademark [11] of fashion products may: 1) stimulate the growth of health trading and industry; 2) provide the guarantee of value and quality of the goods and services for the customers; 3 ) serve as the means of trade promotion and advertising; 5) create and maintain the "goodwill" in foreign market; 6) symbolize the foreign market expansion and maintenance.

However, up to this point, the Laws of Trademark is less effective since the limited amount of the registered products, particularly the fashion products, though the registration fee is affordable. Therefore, the review towards the Laws has not yet reached the society's culture, not to say the least, the less performance of the bureaucracy and institutional registration in protecting the fashion products. Yet, this will affect to the global competitiveness of the products.

Based on the background, the writer is interested in studying the Implementation of TRIPs-WTO in IPR protection over fashion products of the creative industry as an effort to improve global competitiveness.

\section{THEORETICAL BACKGROUND}

Fashion is a creative activity related to the designing of cloth, footwear, accessories, and modern cloth and its accessories [12]. It is one of the creative industry sub sectors [13], an integral part of the creative economy [14] and serves as a strategic plan in improving global competitiveness. Creative economy relies heavily on the creation of goods and services by making use individual skills, talent, and creativity as his intellectual property [14] that needs to be protected through trademark registration [15]. This will differentiate his products to other similar products so that he will be protected from the dirty business.

Law protection over fashion products of the creative industry, as an effort to improve global competitiveness, must be based on the cost and benefit approach and to the development concept as well. In Teori Pembangunan
Hukum, Mochtar Kusumaatmadja [16] says that the role of law in the development is to ensure that the dynamic changes occur in a regular way [16]." Sunaryati Hartono states that the crucial point of law development [17] .

In order to balance the development, legal certainty is required. It can be implemented through the availability of appropriate law [18] to go through the global market. Similarly, this would also apply to fashion that serves as other particular form of copyright in a work of industrial design creativity requiring an adequate protection.

The underlying principle of IPR is that if one creates and innovates something from his intellectual skills, one must get the ownership of natural right, based on the flow of natural law. [19] Grotius argues that the natural law generated from one rational activity is positive that it regulates the principle of giving respects to individual rights [20], and this ownership shall be recognized [20]. To make this possible, government needs to get involved by providing specific protection, as suggested by the concept of modern welfare state. Marbun states that in the modern "welfare state," government should actively participate in any society's activities, through which they can ensure the welfare for their people [21].

The underlying theories of the IPR protection over fashion products are proprietary theory, contract theory, and several supporting theories. The supporting theories are [22] 1) Reward theory; the creator of fashion product is given a reward, recognition, and legal protection over the works and his achievements in designing particular products. 2) Recovery theory; the creator is given an exclusive rights to exploit the given IPR in order to regain what he has been worked out. 3) Incentive theory; incentive is given to stimulate one's creativity. [22] Robert M. Sherwood in Public Benefit Theory [23] suggests that creator must be valued and protected legally so that they can keep on creating products that become the basis of the growing industry and at the same time support the global competitiveness. Additionally, Jeremi Philips and Allsion Firth, in "The Absolute Monopoly of The Market", say that the IPR owner has the right to prevent any individuals in using the rights based on the law protecting it.

\section{RESEARCH METHOD}

The method used is Normative Juridical. It searches, investigates, and examines the object through either library data or secondary data in order to study the law principles in the scope of both national and international laws; Laws of Trademark no 15 year 2001, TRIPs-WTO Treaty, Paris Convention, and Trademark Law Treaty.

The research specifications used is analytical-descriptive aiming at providing description regarding the facts together with the precise analysis to the valid law and regulation. It is also related to the theories of Law and its practices over the IPR of fashion trademark of the creative industry as the efforts to support the global competitiveness.

The steps taken in this study is through the library research and data collection using the study of documenting. The data analysis is the description of the conclusion and the results. Both law materials, primary and secondary data, are analyzed using qualitative method to figure out the 
principles and information. The data are located in Indonesia and other relating countries.

\section{DISCUSSION}

\section{A. The Implementation of TRIPs and WTO in IPR Protection over Fashion Trademark of the Creative Industry}

Trademark as a form of intellectual work of art plays an important role in trade improvement [24]. The trademark and its image, particularly for fashion product of the creative industry, is a guarantee of quality product in global competitiveness. Therefore, trademark - as the asset of the owner-requires law protection over the piracy that has been the concern in many countries. In relation to this, Prof. Mccarthy says that "policies of consumer protection, property rights, economic efficiency and unusual concepts of justice underlie the law of Trademarks" [24].

As the implementation of the trademark protection, in line with the TRIPs and WTO implementation, the Government of Indonesia has enacted the latest Trademark Laws no 15 year of 2001 on the $1^{\text {st }}$ of August 2001. Not until this law, the trademark was protected by the Law No 14 year 1997 regarding The Mending Regulation over the Laws no 19 year 1992 regarding Trademark. The Laws no 15 year 2001 replaced the The Laws No 14 year 1997 jo The Laws No 19 year 1992.

This is in line with the free determine principles contained in TRIPs - WTO treaty that every member country has the rights to determine the ways to apply the requirements in the treaty into its law system and the practices [25]. Similarly, the member countries are obliged to adjust their laws to the internationally agreed conventions of IPR, in accordance with the principle of Intellectual Property Convention. Indonesia has ratified the Trademark Law Treaty in accordance with the Presidential Decree no 17 year 1997.

Though the TRIPs-WTO treaty does not regulate the Trademark requirements in details, the member countries has the rights to determine their own ways, in an appropriate manner, in implementing the trademark requirements noted in the TRIPs-WTO treaty and they should meet the other IPR international conventions.

Subsection no 16 of the TRIPs-WTO treaty regulates that the Rights of Trademark should be protected. As stated in the following:

"The owner of a registered trademark shall have the exclusive right to prevent all third parties not having the owner's consent from using in the course of trade identical or similar signs for goods or services which are identical or similar to those in respect of which the trademark is registered where such use would result in a likelihood of confusion."

Based on the requirement, it can be concluded that the registered trademark owner has the exclusive rights to prevent other third parties, without any owner's consent, to use similar or identical registered trademark so that the owner will have difficulties in differing the products. Therefore, the system, adopted in Laws No 15 year 2001 regarding Trademark, is the Constitutive System regulating that the rights of Trademark will appear as it is registered. It is contained in Subsection 3 of the Laws no 15 year 2001 regarding Trademarks saying that:

"Right to the trademark is the exclusive rights granted by the state to brand owners who registered in the list of common trademark for a certain period of time by using the own brand or give permission to others to use."

Furthermore, Subsection 4 of the Laws No 15 year 2001 regarding Trademark reassures the above mentioned requirements through "the trademark is not registered based on the proposal proposed by individual with no good intention".

Subsection 21 of the TRIPs-WTO treaty regulates the requirements for transferring the registered Trademark Rights:

"Members may determine conditions on the licensing and assignment of trademarks, it being understood that the compulsory licensing of trademarks shall not be permitted and that the owner of a registered trademark shall have the right to assign the trademark with or without the transfer of the business to which the trademark belongs."

Therefore, member countries may determine the requirements on the licensing agreement or trademark transferring. Compulsory licensing of trademarks is not permitted to be transferred and that the owner of a registered trademark has the right to assign the trademark with or without the transfer of the business to which the trademark belongs.

Fashion is a creative activity related to the designing of cloth, footwear, accessories, and modern cloth and its accessories [26]. After the fashion is assigned with trademark or brand, it affects the selling of the products and protects the products [27] from being exploited by the irresponsible parties. It is also a potential economic sub sector that requires the protection of Law through the IPR. [27] Therefore, the registration of IPR is a crucial issue.

Other content of the Trademark Laws No 15 year 2001 subsection 76 is the expansion of the sanction over the laws, particularly those who use identical registered trademarks. The sanction given can be in the form of klatch delict. This means that the report from the owner the violator may be charged. Without the report, there will be no further investigation from the police. Sudargo Gautama says that it is a setback if the sanction and any criminal charges rely heavily on the report [28]. The more effective way in doing this is that if the public prosecutor can initiate the charge itself without the report of the owner [28]. Popular fashion trademark is susceptible of being faked. This results in the owner being deceived and loss.

The conditions of Subsection 18 of the TRIPs-WTO states that the trademark rights shall not exceed the period of 7 years. This has been implemented in Subsection 28 Jo Subsection 35 Act 1 of the Laws No 15 year 2001 that firmly determines the protection period of 10 years and can be extended for the similar period.

This 10 year-period shall apply as long as the owner pays for the fee to the Directorate General of Intellectual Property Right. This extension will be issued as long as there are no content changes from its original certificate [29]. Similarly, this condition applies as long as the goods are still being produced and sold. This condition brings a minor state for the employers. 
In addition to that, Trademark Law does not equalize the protection period of 10 years for every kind of trademarks and brand because this period is relatively short for particular products that require longer time and bigger cost in their productions. Therefore, period grouping is required to encourage the owner's creativity and innovation, as the efforts to improve the global competitiveness.

\section{B. The IPR Protection of TRIPs-WTO over Fashion Product Trademark of the Creative Industry as an Effort to Improve the Global Competitiveness}

In terms of improving competitiveness in global market, countries build creative industry competence through fashion sub sector. This sub sector leads the creative economy by focusing on the IPR-based industries.

The contribution of the creative economy to the global economy can be seen from the data of January 2000 in which its value reached $\$ 2.24$ billion dollar and grew 5\% every year. If predicted using this state, in 2020 the value of creative economy shall reach $\$ 6.1$ billion dollar. In 1999, World GNP reached $\$ 30.2$ billion, the contribution of the creative economy was $7.3 \%$ to the global economy [30]. This requires sufficient IPR protection over the fashion products of the creative industry.

In the international trading, Indonesia's bargaining position regarding the IPR needs for improvement. Any efforts conducted to strengthen the products, from piracy and fabrication, through IPR is often restrained [31]. If it is related with the flow of nature law saying that the major principle of IPR is that any individual who creates and innovates something from his intellectual ability shall have the natural rights [32]. Grotius argues that the regulation of human property [20] puts emphasis on human resources and intelligence [33]. Based on the civil law, the IPR shall be recognized by its owner [33]. Therefore, as a preventive caution from piracy and fabrication of fashion products, the government of Indonesia has adjusted the national law system to meet the conditions of the TRIPs-WTO. As the implementation of that adjustment, the government has now adopted the Constitutive System on the registration system. Therefore, the right over Trademark is issued because of the registration, as described in the Subsection 3 of the Law no 15 year 2001 regarding Trademark.

The principle underlying the registration procedure is the fundamental reason of the particular trademark or brand protection. The registrar shall have the exclusive right in both economic right and moral right called the rights of trademark and brand design. This right can prevent other party to fabricate, imitate, or any other irresponsible actions toward the registered trademarks or the owner. This principle is in line with the Recovery theory [33]; the creator is given an exclusive right to exploit the given IPR in order to regain what he has been worked out.

Fashion, its trademark, as a registered trading product shall be recognized by the government so that the originality is guaranteed [29]. The importance of registration is that written evidence serves as the main evidence. For that reason, Trademark certificate shall be a strong and firm evidence in Courts [34].

In relation to global competitiveness, as the fashion products of creative industry are growing and are exported, advertising and promotion become easier [29]. The fashion products with the registered trademark and brand shall help the owner in gathering loyal consumers since they tend to have their orientation on particular trademark. This way, the customers will easily remember particular product through its trademark [29].

That way, the registration of trademark is a significantly crucial way in order to provide law protection over the fashion product of the creative industry. This concept goes hand in hand with Reward theory [35]; the creator of original design and industry is given a reward, recognition, and legal protection over the works and his achievements in designing particular products. The protection itself assures the law certainty for the creators and owners/inventors of the trademark and prevents violation and criminal action over their trademark right. This way, they can have legal protection and at the same time customers shall be protected from piracy and fabricating.

In line with the Incentive theory; incentive is given to stimulate one's creativity to create unique, new, original, and useful fashion products with particular trademark and brand [35]. This will stimulate the passion of the trademark owner and encourage the development of the creative industry.

However, up to this point, not many trademarks have been registered despite its less expensive fee. Among hundreds small industries of Batik in Yogyakarta, only about 20 industries that have registered their trademarks. The Ministry of Industry has recorded that only 72 Batik registered trademarks in Indonesia; particularly in Java and Madura [36]. The trademark and design owned by the Small and Medium Industry (IKM) in the Regency of Tegal is still small in numbers [29]. Having trademark or brand is one of the investment barriers for the small entrepreneur, yet through product registration they can survive from the foreign products invasion. It is now clearly benefited when the fashion products have their own trademarks. Robert $\mathrm{M}$. Sherwood in Public Benefit Theory [23] states that the owner of fashion products shall be respected and protected by law so that the creativity can be the fundamental in the industrial growth [23], at the same time serves as the effort to improve global competitiveness.

Neglected registration by the inventors of the trademark products and designers causes the less competitiveness in the global market. According to Commercial Advisory Foundation (CAF), in Indonesia trademark plays the role in improving the industries for the investment [37]. Jeremi Philips and Allison Firth, in "The Absolute Monopoly of The Market", argue that the right owner (trademark and designer of the creative industry) shall have the right to prevent any parties in using their property right in the market under the applicable law.

One of the barriers in implementing the Trademark Laws, as the implementation of TRIPs, is that there is gap between the juridical regulation and practical needs in society [38]. This condition holds back the hope of the fashion product owner in protecting the works and causes the lack of global competitiveness.

This case is illustrated in the subsection 18 act 3 of the Laws No 15 year 2001 regarding Trademark stating that the registration of the trademark shall take 9 months as stated in 
the subsection 4, act 5 jo act 6 of the Laws No 15 year 2001 . In this act, it is stated that registration requires inspection over the proposal that may take 1 year. However, in practice it takes 2 to 2,5 years [39]. During that time, the registrar is not allowed to market the product while the trademark is under registration process. This condition inflicts benefit loss to the fashion product owner for it delays the business [39]. This condition causes the ineffective function of the protection over the trademark rights. The registration process and period is susceptible to piracy [39].

Other regulations related to Trademark is referred to Act 27 of the Law No 15 year 2001 discussing the applicable registration fee that shall apply only after the trademark has been registered [39]. Taking this into consideration, if the application is rejected, this means that any fee paid cannot be refunded (subsection 20 act 1 of the Law No 15 year 2001).

The Law no 15 year 2001 needs to be reviewed in its sanctions for the violator. Currently, the law regulates it through klatch delict. This means that the violator can only be charged if the owner proposes a report/klatch. Sudargo Gautama says Sudargo Gautama says that it is a setback if the sanction and any criminal charges rely heavily on the report. The more effective way in doing this is that if the public prosecutor can initiate the charge itself without the report of the owner [39]. Therefore, based on the weakness, this Law needs to be reviewed.

In relation to this, Mochtar Kusumaatmadja, through his Law Development Theory, defines that the role of law as a society's renewal media. The law must meet the society's culture so that it becomes the regulator in the regularly dynamic changes [40]. The law should be responsive and accommodative [41] as well in order to create an effective law. Sunaryati Hartono states that the crucial point of law development comprises the four following concepts [17]: (a). to perfect; (b) to shift into a better and modern system, (c). to make something that does not exist, and (d). to exclude the existing invalid system

As a responsive and accommodative law, during the review, the Trademark Law shall take into account the following factors: philosophical juridical sociological, and international [42].

Philosophical factor is the basic value, the ideal expected by the owner of the trademark and design of the fashion products in Indonesia. The value itself is stated in Pancasila; the balance, democratic characters, justice, and orderliness. Juridical factor. It is industrial design regulation that binds. It is also government initiative to realize the welfare state so the government needs to make positive changes so that the regulation meets the expectation of the fashion product owner and designer. They are potential and may improve the global competitiveness.

Sociological factor. The regulation of industrial design should accommodate the value that is adopted by the owner of fashion products, particularly the traditionally creative works. The works shall represent the typical value of the society because this value is potential and strategic in improving the global competitiveness.

International factor must be taken into account is the principles of Intellectual Property Convention and Trademark Law Treaty. These principles have been implemented in the TRIPs-WTO regulation and are adopted by the Indonesian IPR [43] practices regarding the Trademark regulation.

Since Indonesia has ratified the international conditions, the action of piracy, fabricating, and other irresponsible actions performed by regional or international society may weaken and harm the global competitiveness. Therefore, international sanctions and principles [43] shall apply for the violators. In addition, law review is required by taking into accounts the existing barriers through the structural, substantial, and cultural aspects [44].

The substantial aspect to be noted is the regulation of IPR that explicitly states the protection over the product owner, particularly the traditional works, considering this kind of product has commonly become public's [45]. Other than that, the sanction regulation for the violator shall be more appropriate if the general klatch is used.

The structural aspect is the institution. The government needs to act strategically in organizing the IPR institutions, particularly those that are regional. This way, the institution shall be stronger and are able to function and protect effectively and are integrated [46]. Other than the betterment in institutional registration, this will also disseminate the registration process in every region, not necessarily be centred [47]. Through this regional institution, the creative industry is expected to survive and at the same time monitor any violation [46].

Cultural aspect has something to do with the society's lack awareness in registering their fashion trademark [48] due to lack of information regarding the importance of trademark registration [29]. Therefore, information dissemination of Trademark Law is required, as well as the dissemination of other related regulation in TRIPs-WTO, to the government official, police official, and society.

\section{CONCLusions AND SugGeStions}

\section{A. Conclusions}

1) In accordance with the free determine principle in TRIPs-WTO, Intellectual Property Convention principle, and Trademark Law Treaty, IPR trademark protection as the implementation of TRIPs-WTO has not fully provided protection over the fashion products of the creative industry. The less appropriate regulation consists of kind of klatch for the violator is klatch delict, yet general klatch will be more effective. The other issue is that there is not yet any spot for regulating the folklore fashion trademark or the traditional knowledge, which is actually potential and strategic for the development of creative industry. Finally yet importantly, the issue of regulating the period of extension that does not consider the kinds of the trademark products.

2) The Laws No 15 year 2001 regarding Trademark, as the implementation of TRIPs-WTO, has not been effectively used by the owner of the fashion product. This weakens the global competitiveness. There are several minor issues regarding this Law, they are inappropriate substantial regulation, long and complex institutional registration, and the lack awareness of 
society regarding the importance of IPR over fashion products, as a strategic way to improve the global competitiveness.

\section{B. Suggestions}

1) In accordance with the Free Determine principle in TRIPs-WTO, the government needs to review immediately the Laws No 15 year 2001. The review may be focused on the substantial, structural, cultural, philoshopical, sociological, jurisdical, and international aspects serving as a firm foundation for the owner to protect his creative products. In addition, the affiliated party needs to disseminate the information; regarding the regulation of Trademark Law and other related international conditions and conventions of TRIPsWTO, to the government officials, law enforcer, and the societies.

2) Institutional organizing is required to simplify the registrational beuracracy and to create the opportunity of regional registration by recording the regional officers performing the task.

\section{REFERENCES}

[1] The development of Indonesia's creative economy 2025, Plans for Improving National Creative Industry 2009-2015, Commerce Department of Republic of Indonesia, p. 1.

[2] Ryan, "The Data from the United Nation in 2003 Regarding the Development of Creative Economy 2025," Plans for Improving National Creative Industry 2009-2015, Commerce Department of Republic of Indonesia, p. 26.

[3] The development of Indonesia's creative economy 2025, Plans for Improving National Creative Industry 2009-2015, Commerce Department of Republic of Indonesia, p. 2.

[4] The development of Indonesia's creative economy 2025, Work Program Improving National Creative Industry 2009-2015, Commerce Department of Republic of Indonesia, p. 1.

[5] The development of Indonesia's creative economy 2025, Work Program Improving National Creative Industry 2009-2015, Commerce Department of Republic of Indonesia, p. 7.

[6] The development of Indonesia's creative economy 2025, Work Program Improving National Creative Industry 2009-2015, Commerce Department of Republic of Indonesia, p. 16.

[7] D. S. Dewanthi, "The Impacts of Social Factor-Introduction to piracy," Faculty of Economy, Indonesia University, 2008, p. 4.

[8] J. M. Sidik. (May 2010). Proven to be plowed, Versace gain Rp184 billion. Antara News. [Online]. Available: http://www.antaranews.com/berita/185840/terbukti-dibajak-versaceperolehrp184-miliar

[9] E. Rajagukguk, "The Role of Law in the development in the globalization era," The Journal of Law, no. 11, vol. 6, p. 115, 1999.

[10] S. Rahardjo, "Problems in socio-cultural diversities in national law reformation moving towards civil," in Proc. National Seminar of Law VII: Law Reformation to Welfare Society, Jakarta: BPHN-Dep. of Law of Republic of Indonesia, 1999, p. 4.

[11] J. R. Saul, "The collapse of globalism and the reinvention of the world," in Proc. National Seminar of Law VII: Law Reformation to Welfare Society, Yogyakarta: Pustaka Pelajar, 2008, p. 238.

[12] The Development of Indonesia's Creative Economy 2025, Plans for Improving National Creative Industry 2009-2015, Commerce Department of Republic of Indonesia, p. 5.

[13] N. Nurani, "IPR protection over the merchandise works of creative industry to improve indonesia economic development," International Journal of Research in Management, p. 4, issue 2, March 2012.

[14] E. Irawan, "The Definition of Musical art Foundation and Pillars," The Development of Kreatif Economy, IPR Media, vol. 4, no. 4, Aug. 2008.

[15] Definition of Trademark, Subsection 1 of the Law No. 15, 2001.

[16] N. Nurani, "IPR Protection of Industrial Design Creativity for Micro Small and Medium Industry as an Effort to Improve National Competitiveness in Free Trade," in Proc. Second International Conference on Business and Economic Research (2 $2^{\text {nd }}$ ICBER 2011), Lengkawi Kedah, Malaysia, March 2011, p. 4.
[17] N. Nurani, "IPR protection over the merchandise works of creative industry to improve Indonesia economic development," International Journal of Research in Management, issue 2, p. 6, March 2012.

[18] R. F. Mayana, "Design protection related to Indonesia economic development," The Free Trade Era, Thesis, Unpad, p. 44, April 2002.

[19] T. Huijbers, The Philosophy of Law in the History Line, p. 60 , Kanisius, Yogjakarta, 1982.

[20] E. Damian, "The legal of copyrignt according to several international conventions, ccpyright acts 1997 and its protection over books and publishing consent," Alumni, Bandung, 1999.

[21] M. Mahfud, The Pillars of State Administration, Liberty, Jogjakarta, p. 45.

[22] R. M. Sherwood, "Intellectual property and economic development: Wesview special studies in science, tecnology and public policy," Westview Press Inc., San Fransisco, pp. 11-13, 1990.

[23] R. M. Sherwood, "Intellectual property and economic development: Wesview special studies in science, tecnology and public policy," Westview Press Inc., San Fransisco, p. 37, 1990.

[24] Directorate general of small and medium enterprise. (April 2013). Trademark Protection in Indonesia. Department of Industry. Kementerian Perindustrian Republik Indonesia. [Online]. Available: http://www.kemenperin.go.id/artikel/6158/KemenperinBerkomitmen-Melindungi-HKI-Industri-Kecil-Menengah

[25] R. F. Mayana, "Design protection related to Indonesia economic development in the free trade era," Postgraduate Program Thesis, Unpad, p. 44, 2002.

[26] The development of Indonesia's creative economy 2025, Plans for Improving National Creative Industry 2009-2015, Commerce Department of Republic of Indonesia, p. 5.

[27] G. Anta. (February 2008). Trademark influences the sale of fashion products. Bisnis. Bali. [Online]. Available: http://www.Bisnisbali.com/2008/02/16/news/gayahidup/qwe.html

[28] S. Gautama et al., Current Law of Trademark 2001, PT Citra Aditya Bakti, Bandung, p. 27, 2002.

[29] Arifin. The registration of trademark and design shall be conducted by the small-medium enterprise. Akarapi Logo. [Online]. Available: http://desainlogodesign.com/pendaftaran-merek-dagang-dan-desainlogo-perlu-dilakukan-oleh-usaha-kecil-menengah-2453.html

[30] J. Howkins, "The creative economy, how people make money from ideas," Plans for Improving National Creative Industry 2009-2015, p. 5 .

[31] The development of Indonesia's creative economy 2025, Plans for Improving National Creative Industry 2009-2015, Commerce Department of Republic of Indonesia, pp. 68-69.

[32] T. Huijbers, "The philosophy of law in history line," Kanisius, Yogjakarta, p. 60, 1982.

[33] M. Arifin, "The theory of law philosophy, critical analysis on law theorie.,"1990.

[34] The eveidences of HIR are divided into written evidence in the form of certificate and vow. International Journal of Research in Management, issue 2, p. 6, March 2012.

[35] N. Nurani, "IPR protection over the merchandise works of creative industry to improve Indonesia economic development," International Journal of Research in Management, issue 2, pp. 4-5, March 2012.

[36] Handoyo. The Head of Technical Services Development of the Craft and Batik Center. [Online]. Available: http://www.tempo.co/read/news/2011/06/21/090342276/Hanya-20Merek-Batik-di-Yogyakarta-yang-Terdaftar

[37] Putra and I. B. Wyasa, "Aspect-aspect of international Privat law in international business ttransaction," PT Refika Aditama, Bandung, p. 23, 2000 .

[38] N. Nurani, "IPR protection over the merchandise works of creative industry to improve indonesia economic development," International Journal of Research in Management, issue 2, p. 10, March 2012.

[39] U. Pribadi. (August 2008). The aspect of intellectual property right in the development of creative industry in Indonesia. [Online]. Available: http://www.kumham-jogja.info/karya-ilmiah/37-karyailmiah-lainnya/43-aspek-hak-kekayaan-intelektual-dalamperkembangan-industri-kreatif-di-indonesia

[40] M. Kusumaatmadja, "Law of society and national development of law," Binacipta, Bandung, 1976.

[41] N. Nurani, "IPR protection of industrial design creativity for micro small and medium industry as an effort to improve national competitiveness in free trade," in Proc. the Second International Conference on Business and Economic Research (2nd ICBER 2011), Holiday Villa Beach Resort and Spa, Lengkawi Kedah, Malaysia, March 2011, p. 23.

[42] N. Nurani, "IPR protection of industrial design creativity for micro small and medium industry as an effort to improve national a competitiveness in free trade," in Proc. the Second International 
Conference on Business and Economic Research (2nd ICBER 2011), Holiday Villa Beach Resort and Spa, Lengkawi Kedah, Malaysia, March 2011, p. 12.

[43] R. F. Mayana, "Design protection related to Indonesia economic development in the free trade era," Thesis, Postgraduate Program, Unpad, p. 266, 2002.

[44] R. F. Mayana, "Design protection related to Indonesia economic development in the free trade era," Thesis, Postgraduate Program, Unpad, p. 377, 2002.

[45] M. R. Ayu. (December 2007). Batik. [Online]. Available: http://batikpekalongan.wordpress.com/2007/12/09/hak-moralindikasi-asal-dan-hak-kebudayaan/

[46] Executive director of IPR center and lecturer of faculty of law. Indonesia University of Islam Yogyakarta. [Online]. Available: http://www.iprcentre.org

[47] A. Sisworiyanto. (Saturday 24, 2012). IPR empowerment for improvment local superior produk and traditional cultur. Sahid Jaya $\begin{array}{llll}\text { Hotel. } & \text { p. } & \text { [Online]. Available: }\end{array}$ http://www.solopos.com/2010/04/25/minim-industri-kreatif-yangdidaftarkan-hki-19772

[48] Supanto. (April 25, 2010). Minim, CREATIF industry with IPR registered. The Head of Center of Study Development and IPR Services, Research and Social Responsibility Institution of UNS Solo. [Online]. Available: http://www.solopos.com/2010/04/25/minimindustri-kreatif-yang-didaftarkan-hki-19772

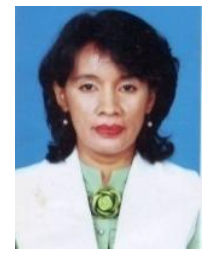

Nina Nurani is a lecturer of State Widyatama University. She joined the Faculty of Business and Management of Widyatama University since 1989 . Her research interests cover intellectual property rights in creative industry. She is a professor candidate of business law in Widyatama University. 